\title{
SASI - BASED PROTECTION FOREST STRATEGY IN MALUKU $(\mathrm{AMBON})$
}

\author{
Aarce Tehupeiory ${ }^{*}{ }^{\circledR}$
}

${ }^{* 1}$ Magister of Law Department, Postgraduate Program Universitas Kristen, Indonesia

DOI: https://doi.org/10.29121/granthaalayah.v9.i3.2021.3809

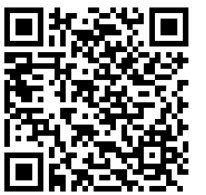

Article Type: Research Article

Article Citation: Aarce Tehupeiory. (2021). SASI - BASED PROTECTION FOREST STRATEGY IN MALUKU

(AMBON). International Journal of Research -GRANTHAALAYAH, 9(3), 221-228. https://doi.org/10.29121/granthaa layah.v9.i3.2021.3809

Received Date: 10 March2021

Accepted Date: 31 March 2021

Keywords:

Sasi-Based Protection

Local Wisdom

Sago

Covid-19

\section{ABSTRACT}

This research is about Sasi-based protection forest strategy, it is done to find out how the Sasi-based protection strategy mechanism in protecting the forest. The research method used is a qualitative research method with a normative legal research. The research was conducted at Universitas Kristen Indonesia from January to March 2021. The objects studied in this study were documents either in reports or regulations related to indigenous peoples' local wisdom. The research instrument used was a document checklist. The data analysis technique used is the descriptive analysis technique. The result of the research is that traditional Sasi wisdom has values and norms to protect forests, water sources, annual plants and food plants. With the concept and understanding of how environmental managers with various customary rules to obtain benefits and maintain the kinship value of area units that already have an identity and must continuously be maintained in the aftermath of the COVID-19 pandemic. Besides, food security for indigenous peoples on the island of Maluku (Ambon) during the Covid-19 pandemic, namely by building food security by encouraging a new paradigm based on local food with directions and policies for developing food security and absorption of dryland technology to support sustainable food self-sufficiency through sources.

\section{INTRODUCTION}

One of the factors that caused the failure of positive laws in forest protection was eliminating taboos and prohibitions on forests that indigenous communities had practiced for centuries as part of local forestry law content. Besides, residents around the forest are less involved in maintaining the surrounding forest, which should be they are the ones who move quickly and report every act of forest destruction that occurs in their area [1]. However, because the prevailing forest protection law system alienates people around the forest, people tend to ignore forest encroachment cases, even though they are aware of it. The village community considers the responsibility for forest protection to be the authority of the forestry police apparatus.

The forest condition, which is getting more and more damaged due to encroachment by irresponsible people, is evidence that there has not been any cooperation between the government and the customary law community [2]. Therefore, sustainable and equitable forestry development can be achieved if there is a paradigm shift. The new paradigm of forestry development is a shift in orientation from forest management to resource-based management,

(C) 2021 The Author(s). This is an open access article distributed under the terms of the Creative Commons Attribution License, which permits unrestricted use, distribution, and reproduction in any medium, provided the original author and source are credited. 
centralized management to decentralized and more equitable resource management. For this reason, customary law communities living around the forest need to be involved as mandated by law.

In the era of regional autonomy, it is worth considering efforts to revitalize the participation of customary law communities in managing, maintaining forest sustainability by conducting a review, directing the pattern of forest protection regulations by adopting local law values that had been in effect during the pre-state law (state law). Opportunity to re-enforce local legal rules constitutionally has a foothold based on the 1945 Constitution of the Republic of Indonesia Article 18 B paragraph (2), which states that "The State recognizes and respects indigenous peoples and their traditional rights as long as they are alive and following the development of society and the principles of the Unitary State of the Republic of Indonesia, which are regulated in law" [3].

Besides, the operational juridical recognition of customary law communities has a legal basis in Law Number 5 of 1960 concerning Basic Agrarian Principles. Article 3, in essence, determines "... the exercise of customary rights and similar rights from customary law communities, as long as they still exist, it must be in such a way that it is in line with the national and state interests ... ". Besides, Law Number 41, the Year 1999 concerning Forestry in Article 67 also recognizes customary law communities. The recognition of the existence of customary law communities is also strengthened in Law Number 32 of 2004 concerning Regional Government in Article 2 paragraph (9), which stipulates that the state recognizes and respects indigenous peoples and their traditional rights as long as they are still alive and following the development of society and the principles of the Unitary State of the Republic of Indonesia [4].

The forest in the local legal conception of the six indigenous communities of Maluku (Ambon) is a place that is overgrown with a wide variety of large trees hundreds of years old, high density and humidity, and a place to live various types of wild and wild animals and even spirits. The concept of forest in local law contains the philosophy of life that all kinds of living things in the forest, whether in the form of plants, animals, even supernatural beings, each have their function and role, which synergistically maintains order, goodness and balance of nature [5]. Order, goodness and balance of the universe concerning forest functions, such as not occurring floods, landslides, drought, maintaining soil fertility, and preventing the occurrence of other natural disasters can disturb the tranquillity and peace of life of all community members, such as epidemics of infectious diseases and wild animal disturbances.

Forest, part of the land in customary law communities, is jointly owned. Only the right to use it is the individual. Forests as joint property rights have developed in every indigenous community in Maluku (Ambon), while management rights are granted based on a customary agreement that binds each member of the clan. The community uses forest resources to ensure the survival of individuals, groups and even clans [6]. Ownership rights over forests reside with the customary law community unit, which is called marga in the Maluku (Ambon) area.

In contrast, the right to manage is given to a member of the customary law community concerned about the customary rights over the forest with all its inherent obligations. A member of an association has the right to open land (forest) to work the land continuously and plant trees to have ownership rights over the land. If the lands are abandoned and no longer taken care of for years, the lands will be controlled again by ulayat rights. "The legal relationship between customary law communities and their territorial forests creates rights that give the community, as a legal group, the right to collect forest products for the welfare of the community. It is the original and primary right under local law covering all forests in indigenous and tribal peoples.

Regarding the information above, the implementation of forest protection must be increased immediately. One way that can be done in Maluku (Ambon) is by implementing the Sasi policy. Sasi is a local with values and norms to protect forests, water sources, annual plants (Sago), food crops, nutmeg plants, trees that are hundreds of years old or forest trees. So, this research describes the traditional sasi, which has values and norms to protect forests, water sources, annual plants (Sago), food crops, nutmeg plants, trees that are hundreds of years old or forest trees. It is the source of life for indigenous peoples to benefit and maintain the kinship value of an area unit that already has an identity and is continuously obliged to be maintained. In particular for indigenous peoples in preventing a food crisis. To realize food sovereignty through local food sources, Sago as a source of food and community nutrition is a typical food from Maluku province (Ambon Island). The community's role on the island of Ambon (Maluku) in realizing food sovereignty is essential to discuss in the Easter Covid-19 pandemic [7],[8]. Therefore, through the realization of indigenous peoples' role in environmental management and traditional local wisdom, sasi is an interesting issue to discuss by giving birth to a new paradigm, namely the paradigm of environmental management of various local food security. One of them is very important in the food tradition of eastern communities such as Maluku, where local food sources such as Sago and tubers have lived with local people together for thousands of years and continue to be a saviour of nutrition the Covid-19 pandemic [9]. 
Aarce Tehupeiory

Therefore, reserchers are very interested in studying forest protection based on Sasi. The problem addressed in this study is implementing a strategy for forest protection based on Sasi in Maluku (Ambon).

\section{METHOD}

The research method used is a qualitative research method with a normative legal research design (in the form of an inventory of local laws (customary law or customary rules that have been stated in written form such as functionary decisions, village regulations, etc.). It is done to see how the legal work mechanism. The research was conducted at Universitas Kristen Indonesia from January to March 2021. The objects studied in this study were documents either in reports or regulations related to indigenous peoples' local wisdom, and the instrument used in this research is a document checklist. The data analysis technique used is the descriptive analysis technique. The data obtained, compiled in the manner described above, will be systematically compiled for subsequent content analysis qualitatively and finally written what should be done (perspective).

\section{RESULT AND DISCUSSION}

The term local law denotes the law that is currently in force and maintained at the local level, regardless of where the law originates, and one of those local laws is customary law. Local law is not limited to customary law but includes all written and unwritten regulations currently or have ever been in effect in an area [10]. Local law in the context of this research includes local laws in six indigenous communities in Bengkulu which are unwritten, such as the customary forestry laws of Rejang, Serawai, Pekal, Lembak, Mukomuko, Kaur, and Sasi, which contain regulations regarding forest protection, and customary law. Thus, the limitation of local law in this study is customary law itself as the most dominant rule enriching local legal rules, and other rules which have initially been elements of customary law but have been given a written form, such as the Sasi Law as one of the strategies that can protect Forest.

Sasi is a prohibition to take something that has been determined not to be taken for a particular time, and if someone violates it, it will bring danger to those who take it [11]. This sasi is usually opened when it has been determined and something that is prohibited can be taken to be appropriately used for the community. The problem after the Covid-19 pandemic is not just a health problem but has had a widespread impact on various aspects of life, including economic, social, cultural and legal fields [12],[13]. One of them is the spike in cases after the Covid -19 pandemic, the uncertainty of food and economic needs in each region. For areas that are red zones for the Covid-19 pandemic, supervision of the distribution of goods and services, including food needs, is limited.

Indonesian Customary Law gives the meaning that customary law communities in Indonesia can be divided into two groups according to the basic structure, namely based on the relationship of a descent (genealogy) and based on the regional environment (territorial). With the above definition, the customary community is a community unit that regularly resides in a particular area, has a leader and has tangible and intangible wealth and can utilize and preserve local wisdom resources carried out by the community. For example, with their local wisdom, the indigenous people of Maluku are Sago as a local food source with local communities for thousands of years.

Local wisdom consists of two words: wisdom and local. Local means local, while wisdom is the same as wisdom. In general, local wisdom can be understood as local ideas that are wise, full of wisdom, of suitable value, which are embedded and followed by members of the community. Local wisdom is found in society, community and individuals [14]. Thus, local wisdom is a traditional view and knowledge that becomes a reference in behaviour and has been practised from generation to generation to meet the needs and challenges in a community's life. Local wisdom has a function and meaning in society both in the preservation of natural and human resources, customs and culture, and beneficial for life.

The local wisdom regulated in Article 1, number 30 of Law No. 30 of 2009 states that local wisdom is noble values that apply in the order of community life to, among others, protect and manage the environment as a whole. Natural resource utilization policies must have a macro vision to create a sustainable ecology. Meanwhile, the micro vision is to maintain sustainable types of diversity. Besides, natural resources must also have a current sense of intergenerational justice (between community groups) and intergenerational justice. Local wisdom creates harmony between nature and society. Local wisdom grows from the community's character and culture, which is rooted and has been passed down from generation to generation as a way of life to unite social culture with the natural surroundings [15]. For indigenous people, they place natural problems as a form of interaction in responding to all 
human behaviour (society) that treats them. God created man as a leader on earth to manage nature with everything in it ideally and adequately to help humans continuously. Humans' process of managing nature needs to be seen whether the treatment is in the context of obedience or evil so that nature will balance with its strength because nature has absolute obedience to God. Utilization of nature in this view is not only in terms of knowledge about the universe as a system but also in social phenomena that arise from interactions between humans and their various problems.

Human behaviour can be observed, cared for, understood and lived, giving birth to awareness and belief in the truth concerning normative values (law), not only must be obeyed as an obligation but also awareness and belief in the generosity or wrath of nature, which constantly directs humans towards safety and welfare or vice versa to destruction/disaster. Local wisdom contains meaning as a form of the harmonious relationship between humans and nature or vice versa; local people understand the wisdom in its totality in utilizing natural resources. Adherence to customary law (ulayat), which is a legacy from previous generations, must be adequately utilized due to future generations' impact [16]. Natural resources are used optimally but not for use because there are rights for the next generation. Therefore, natural resources must be managed optimally and sustainably in a long-term process as the basis for sustainable development to be passed on to future generations.

Meanwhile, environmentally sustainable development is a translation of "sustainable development", the concept of development which was previously known, is more popularly used as the term "environmentally sound development" as a translation of "Eco-development" [17]. The above affirmation shows that environmentally sustainable development is closely related to natural resources utilization as an asset to create people's welfare. Article 1 point 3 of Law No. 30 of 2009 states that sustainable development is a conscious and planned effort that integrates environmental, social and economic aspects into a development strategy to ensure environmental integrity and safety, capability, welfare and quality of life of future generations.

Development is basically about creating and improving welfare for society in a sustainable manner, and it is marked by positive economic growth. Utilization of natural resources is one of the capitals of the regional development process. Regional development will be sustainable (sustainable) if the sources of growth are maintained at all times [18]. Therefore, it is essential to preserve natural resources for the benefit of present and future generations. For Indonesia, a reliable contribution in contributing to economic growth and a source of foreign exchange and development capital is from natural resources. Natural resources have an essential role in the Indonesian economy in the past, present and future.

On the other hand, the sustainability of its availability is often ignored. Besides, the rules must be adhered to as a basis for business management implementation and supporting the economic development sector. There is a tendency for a decrease in the carrying capacity of the environment and the depletion of the availability of natural resources, and a decrease in the environment's quality [19]. In general, it can be said that all types of natural resources and their environmental components must be managed following their carrying capacity. In various indigenous communities in the Maluku Islands and North Maluku, there are systems of allocation management (use) and integrated management of land and sea ecosystems that are distinctly local, complete with traditional institutions that ensure that these local systems work effectively. To date, only a tiny part of modern science has known about these local systems.

Local wisdom about the customary tradition of sasi, which is still widely found in most Maluku parts, regulates the sustainable use of certain areas and biological species. Sasi prohibits extracting natural resources in an area for a certain period, usually six months to one year. The goal is to preserve the environment and ensure more quality and outstanding results in the future. The essence of sasi is very noble for the community's welfare and the preservation of natural resources [20]. Sasi begins with a traditional ceremony, then a prayer by traditional leaders, and ends with the installation of sasi in three yellow janur and ai num wood embedded in the sasi location. One example of the implementation of sasi in Taar Village is the prohibition of anyone taking fish from Teluk Un. After one year, the implementation of the sasi was opened (the sasi was revoked). The fish results in Un Bay were abundant because of the abundance, some of the fish was sold, and the money was used to build village infrastructure, including building a new church. Sasi is also often used to protect forests or is routinely used to ensure the Lola (clam) population; wherever sasi is installed, indigenous people refrain from violating it. They believe that if it is violated, a disaster will immediately fall upon them.

Maluku Province has an area of 712,479.65 km with a sea area of 658,294.69 km2 and an area of 54,185 km2 with 1,340 islands divided into 1,336 small islands, four large islands with islands on the border of 19 islands with a long coastline of 10,630.10 km, Regency/City 9/2 Regencies/Cities with a population of 1,829,228 people, density: 
32 people $/ \mathrm{km}$. The Head of the Agriculture Office continued by stating that the area's characteristics were divided into Central Maluku, consisting of Ambon, West Seram, East Seram, South Buru, Banda Sea, Southwest, Southeast Maluku (Tual City, Aru Islands), and West Southeast Maluku [21]. In connection with food security in Maluku province, the issue of Maluku food, among others, is that it still requires food supply outside the areas classified as food deficit areas). Subsequently, there was a change in the pattern of consumption of food sources of carbohydrates to rice, and this was because it was practical in processing and easy to obtain, and could be stored for a long time and was prestigious besides being available at any time and place. This change in food consumption patterns resulted in a change that resulted in $53 \%$ of monthly household expenditure on rice, so that $27.3 \%$ of the causes of poverty from the food group were rice. With the ratio of cities: $27.65 \%$, Village; $27.25 \%$.

Based on the data above, in the post-Covid-19 pandemic, the agricultural sector takes place in the short and long term because it can accumulate with other influences such as climate change, including the production of food insecurity commodities, inflation as well as the supply chain for marketing of products and purchasing power of farmers [22]. Therefore, the plan to increase food security in the agricultural sector in the Maluku province is carried out by the Head of the Agriculture Office of Maluku province. Namely by First, increasing the production capacity of strategic food commodities, which consists of; accelerated planting of strategic food commodities, namely 700 Ha of lowland rice, $450 \mathrm{Ha}$ of Biofortified rice, $450 \mathrm{Ha}$ of Biofortified rice, $1500 \mathrm{Ha}$ of field rice, 10,000 Ha of corn, $30 \mathrm{Ha}$ of shallot and $165 \mathrm{Ha}$ of chilli. Furthermore, the distribution of pre-harvest and post-harvest facilities and climate modification of vegetable crop screens. Second, the development and utilization of local food, which is divided as well, encourages related agencies to move the planting and utilization of local food as well as the development of local food sources of carbohydrates substituting for rice, cassava (10 Ha), taro (8 Ha), Sago (50 Ha) and animal food development (ungags-Ruminausia). Third, Human Resource Development, namely Cyber Extension to farmers in the BPP area. By disseminating the impact of Covid-19, Demonstration Forming, communication media (cultivation and marketing). Fourth, increasing farmers' income through labour-intensive activities, namely rehabilitation of tertiary networks of 1200 hectares and rehabilitation of patterns of 200 hectares. The local wisdom of indigenous peoples in Maluku in realizing food sovereignty is reflected in interventions to increase food availability in the post-Covid19 pandemic era.

Through measures to overcome food insecure areas in Maluku province, an effort to address food vulnerability was carried out using food availability, food affordability and food utilization. This food insecurity and an investigation was carried out consisting of chronic prone interventions which included looking at how is the problem of food availability by assessing the insufficient capacity of the population's consumption demand, which is divided into how to increase production capacity [23]. Then also diversification of food consumption, then intervention by looking at access to food, limited purchasing power due to poverty. It correlates with employment opportunities and easier access to food and social safety nets for poor households. The problem of infrastructure, limited access to clean water, and electricity is related to the construction of basic infrastructure (clean water, electricity). The last one is health and nutrition problems. It is related to the high stunting of children under five and the unequal distribution of health workers; this is done by providing counselling on nutrition and child care, food consumption for B2 SA, environmental sanitation facilities, and health workers' provision [24].

From the efforts to address food vulnerability carried out by the Food Security Service in Maluku province nationally by improving the national logistics system, this takes a relatively long time. Therefore, the Ministry of Agriculture should encourage people in areas that are vulnerable to food insecurity to provide their food. A variety of nutritionally balanced man funds through activities. Sub-district-based family farming/family farming (farmer family) by assisting in land and yard use was also shown in the youth group with the assistance provided, namely the nursery so that education and technology trials could be carried out, namely agricultural education in schools [25]. It is done by selecting locations in areas that are vulnerable to food insecurity. Furthermore, agricultural, fishery and aquaculture cultivation activities are carried out, and animal husbandry and strategic marketing.

According to the author, it is time for the paradigm of national food security in the post-Covid-19 pandemic to shift to traditional sasi following each region's natural conditions, especially in the Maluku province pandemic. It is based on local food that has been handed down by God "Gift" for free. . to every customary person/community in Maluku province based on the districts and sub-districts in Maluku province. Those who live in various districts and sub-districts survive with a variety of local food sources, namely by giving birth to a new paradigm (The New Paradigm). The local-based food security paradigm is put forward for the indigenous Maluku community, namely Sago, by carrying out the sago planting movement by encouraging the commitment of the local government and involving youth and equality of gander to become farmers by being provided with counselling on the theme of Sago 
self-sufficiency supported by the provision of vocational education, training, mentoring and implementation of technology[26]. Likewise, strengthening access of farmer families to capital, production facilities, and farm insurance with the development of diverse food cultivation, processing, and marketing of agricultural products to sustain farming and maintain biodiversity. A budget must support it, policies, imports, and preferably following the natural conditions of Maluku province both in the districts and sub-districts where the community is located, besides that the strategy and policies for Sago in Maluku province are made, namely the sago culture strategy as a local food belonging to the Maluku tribe. Therefore, it is also necessary to develop food barns for indigenous peoples of Maluku, which are carried out by building activities and filling food barns for customary law communities, with implementation support, namely empowering guidance and collecting as well as technical guidance for community food barn management with funding sources from the state budget, provincial budget. Regencies/cities, nongovernmental customary law communities, and other non-binding sources. All of this increased food availability and affordability in areas in the Maluku province in the post-Covid-19 pandemic.

With sufficient food, this is the right of every human being. It means that every person and every customary law community in every district and sub-district in Maluku province has the right not to be hungry and have access to adequate, nutritious food and human funds for their health[27]. Therefore, food security is access to adequate morning baby for everyone at any time to obtain a healthy body and an active life. Furthermore, this must be supported by applying dryland technology to support sustainable food self-sufficiency for indigenous peoples in small islands in Maluku province in the post-Covid-19 pandemic.

Geographically, Maluku province has a land area, 829,727 Ha of dry land, which is bigger than the wetland area of only $24,422 \mathrm{Ha} .8$ It is further in reality that the rice field printing program is more significant than the dry land printing program. Due to the decline in national food production, which is being felt at this time by the narrower area of productive agricultural land. To increase the potential for crop production, one of the alternative options expected to meet food needs is the utilization of dry land. A strategy is needed to increase dryland production, printing dry land, not just paddy fields[28]. It is intended that dryland farming is needed explicitly for indigenous peoples, namely Maluku farming communities, because this follows the local agroecology and socio-culture, of course, and is supported by the Indigenous Knowledge and the local wisdom of indigenous peoples in Maluku province. With dryland farming land now or as little as possible, and as much as possible. It depends on the climate, which will ultimately produce the results of the farming. Likewise, a strong commitment from the central and local governments is also needed. It can be done in stages, with careful planning and then a careful calculation of inputs and outputs for the short, medium and long term. It is the form of partisanship of the government towards farmers, especially within the customer community's scope to traditional sago farmers in Maluku.

It is in line with environmental management, an integrated systematic effort to preserve environmental functions and prevent environmental pollution or damage, including planning, utilization, control, maintenance, supervision, and law enforcement. From this, it turns out that the problem of environmental management on the island of Ambon (Maluku) after the Covid-19 pandemic turns out that environmental management and traditional wisdom of sasi are natural and environmental sources [29]. Therefore, it is necessary to have an environmental management effort and an effort to utilize the environment that cannot be separated from environmental permits and environmental risk analysis and overcome environmental pollution and environmental functions. It means that sasi is a restoration of environmental functions and the maintenance and supervision of law enforcement following the law regulating traditional wisdom. Furthermore, environmental sustainability is guaranteed by the welfare of the community and the preservation of natural resources. Furthermore, in taking forest products, Sago, cutting one sago tree, and cutting the tree are required to replace it by planting ten sago palms. Thus, environmental management and traditional wisdom of sasi on the island of Ambon (Maluku) after the Covid-19 pandemic in managing natural resources, the central government must also pay attention to the food needs of indigenous people living on the island of Ambon (Maluku) with policies on managing and managing natural resources with traditional wisdom on the island of Ambon (Maluku).

\section{CONCLUSION}

Based on the above discussion, it can be concluded that traditional Sasi wisdom has values and norms to protect forests, water sources, annual plants (Sago, etc.) and food plants. With the concept and understanding of how environmental managers with various customary rules to obtain benefits and maintain the kinship value of area 
units that already have an identity and must continuously be maintained in the aftermath of the COVID-19 pandemic. Besides, food security for indigenous peoples on the island of Ambon (Maluku) during the Covid-19 pandemic, namely by building food security by encouraging a new paradigm based on local food with directions and policies for developing food security and absorption of dryland technology to support sustainable food self-sufficiency through sources. Local food, namely Sago and tubers, which are the saviours of community nutrition during the Covid-19 pandemic, and the community can stay alive by sustainably managing natural resources.

\section{SOURCES OF FUNDING}

This research received no specific grant from any funding agency in the public, commercial, or not-for-profit sectors.

\section{CONFLICT OF INTEREST}

The author have declared that no competing interests exist.

\section{ACKNOWLEDGMENT}

None.

\section{REFERENCES}

[1] Ostrom, E., \& Nagendra, H. (2006). Insights on linking forests, trees, and people from the air, on the ground, and in the laboratory. Proceedings of the national Academy of sciences, 103(51), 19224-19231.

[2] Mitchell, R. E. (2006). Environmental governance in Mexico: Two case studies of Oaxaca's community forest sector. Journal of Latin American Studies, 519-548.

[3] Bedner, A., \& Van Huis, S. (2008). The return of the native in Indonesian law: Indigenous communities in Indonesian legislation. Bijdragen tot de taal-, land-en volkenkunde/Journal of the Humanities and Social Sciences of Southeast Asia, 164(2), 165-193.

[4] Commo, L. U. C. 2) The constitutional rights of indigenous peoples to gain recognition and respect regarding their traditional rights. The meaning of Article 18 B Paragraph (2) of the Constitution of the Unitary State of the Republic of Indonesia 1945, is also a constitutional mandate that must be.

[5] Melaku Getahun, J. (2016). Oromo indigenous knowledge and practices in natural resources management: Land, forest, and water in focus. J Ecosys Eco graph, 6, 181.

[6] Ballard, H. L., Fernandez-Gimenez, M. E., \& Sturtevant, V. E. (2008). Integration of local ecological knowledge and conventional science: a study of seven community-based forestry organizations in the USA. Ecology and Society, 13(2).

[7] Nadeak, B., Naibaho, L., \& Silalahi, M. (2020). COVID-19 and Students' Anxiety Management. International Journal of Innovation, Creativity and Change, 13(7), 1574-1587.

[8] Tyas, E. H., \& Naibaho, L. (2020). A harmony among of religious community is required amidst the covid-19 pandemic. International Journal of Research-GRANTHAALAYAH, 8(9), 422-428.

[9] Rato, D., Utomo, L., Jayantiari, I. G. A. M. R., Bustami, S., Tehupeiory, A., Trisia, M. A., ... \& Geme, M. T. (2020). Local Wisdom of Indigenous Law Communities in Realizing Food Sovereignty Amid the Covid Pandemic 19. Journal of Indonesian Adat Law (JIAL), 455-455.

[10] Tehupeiory, A., Widiyani, I. D. A., Tobing, G. L., \& Napitupulu, D. (2020). Counseling the Importance of Land Registration in the Assisted Village of Pematang Sidamanik District, Simalungan Regency. JURNAL Comunit $\tilde{A}$ Servizio, 2(1), 312-320.

[11] Sihombing, S. M., Tehupeiory, A., \& Harjono, D. K. (2021). Analysis of Law Synchronization Number 20 of 2011 concerning Flats with the Regulation on Flat Development Related to Certainty of Consumer Legal Protection (Studies at DKI Jakarta Flats). to-ra, 223-234.

[12] Sormin, E., Harefa, N., Sitompul, F., Arodes, E. S., Cing, J. M., Tehupeiory, A., ... \& Azzahra, S. F. (2020). Action of UKI: a care on Preventing the Spread of the COVID-19. JURNAL ComunitÃ Servizio, 2(2), 471-478. 
[13] Van Bavel, J. J., Baicker, K., Boggio, P. S., Capraro, V., Cichocka, A., Cikara, M., ... \& Willer, R. (2020). Using social and behavioural science to support COVID-19 pandemic response. Nature human behaviour, 4(5), 460-471.

[14] Tehupeiory, A. (2020). Ulayat Right is recognized in the 1945 Constitution. Inakoran.com.

[15] Chuenrudeemol, W., Boonlaor, N., \& Kongkanan, A. (2012). Design process in retrieving the local wisdom and communal identity: A case study of Bangchaocha's bamboo basketry crafts.

[16] Mulyani, L. (2020). Reforming Group Legal Personhood in Indonesian Land Law: Towards Equitable Land Rights for Traditional Customary Communities (Doctoral dissertation).

[17] Glassman, J., \& Sneddon, C. (2003). Chiang Mai and Khon Kaen as growth poles: regional industrial development in Thailand and its implications for urban sustainability. The Annals of the American Academy of Political and Social Science, 590(1), 93-115.

[18] Jovovic, R., Draskovic, M., Delibasic, M., \& Jovovic, M. (2017). The concept of sustainable regional development-institutional aspects, policies and prospects. Journal of International Studies, 10(1).

[19] Zhong, L., Deng, J., Song, Z., \& Ding, P. (2011). Research on environmental impacts of tourism in China: Progress and prospect. Journal of environmental management, 92(11), 2972-2983.

[20] Zerner, C. (1994). Through a green lens: The construction of customary environmental law and community in Indonesia's Maluku Islands. Law and society review, 1079-1122.

[21] Tehupeiory, A., \& Naibaho, L. (2020). Enhancing community legal awareness of land right disputes through the use of legal aid institutions. International Journal of Psychosocial Rehabilitation, 24(8), 1223-1231.

[22] Obayelu, A. E., Obayelu, O. A., Bolarinwa, K. K., \& Oyeyinka, R. A. (2021). Assessment of the Immediate and Potential Long-Term Effects of COVID-19 Outbreak on Socioeconomics, Agriculture, Security of Food and Dietary Intake in Nigeria. Food Ethics, 6(1), 1-22.

[23] Moroda, G. T., Tolossa, D., \& Semie, N. (2018). Food insecurity of rural households in Boset district of Ethiopia: a suite of indicators analysis. Agriculture \& Food Security, 7(1), 1-16.

[24] De Lange, J. C. (2010). Factors contributing to malnutrition in children 0-60 months admitted to hospitals in the Northern Cape (Doctoral dissertation, University of the Free State).

[25] Vandenbosch, T. (2006). Post-primary agricultural education and training in sub-Saharan Africa: Adapting supply to changing demand. Unpublished manuscript, World Agroforestry Centre, Nairobi, Kenya.

[26] Crane, P. R., Spencer, A., \& Duthie, D. (2018). From institution-centred to place-responsive practicums: Reflections from engagement with the Cherbourg Aboriginal community. Advances in Social Work and Welfare Education, 20(1), 122-138.

[27] Koostanto, H., Zakky, M., \& Soebandino, S. (2016). Addressing the economic and healts challenges facing smallholder communities through roots and tubers in Maluku and Maluku Utara, Indonesia-results of a scoping study.

[28] Kato, F. (2007). Development of a major rice cultivation area in the Kilombero Valley, Tanzania. African study monographs. Supplementary issue., 36, 3-18.

[29] Harkes, I., \& Novaczek, I. (2002). Presence, performance, and institutional resilience of sasi, a traditional management institution in Central Maluku, Indonesia. Ocean \& coastal management, 45(4-5), 237-260. 